\title{
Analysis of Factors Affecting Watermelon Production in Ekiti State, Nigeria
}

\author{
Adojutelegan O.T, Adereti F.O, Makanju T.S* and Olorunfemi O.D
}

\author{
Department of Agricultural Extension and Rural Development, University of Ilorin, P.M.B 1515, \\ Ilorin, Kwara state, Nigeria
}

\begin{tabular}{|c|c|}
\hline Abstract & Article Information \\
\hline $\begin{array}{l}\text { The study analysed the factors affecting watermelon production by watermelon farmers in } \\
\text { Ekiti State, Nigeria. A snowball sampling technique was adopted in the selection of forty } \\
\text { two watermelon farmers. Data were analyzed by descriptive statistics, Pearson Product } \\
\text { Momment Correlation (PPMC) and factor analysis. Findings showed that } 64.3 \text { percent of } \\
\text { watermelon farmers were found in Ise Ekiti. The mean score of the respondent's age was } \\
39 \text { years, } 76.2 \text { percent of them were married with } 10 \text { years of farming experience. The most } \\
\text { commonly grown watermelon variety was sugarbaby, 50percent of them used both } \\
\text { personal and hired labour and } 45.2 \text { percent produced greater than } 20 \text { tons/ha of } \\
\text { watermelon. Majority of the farmers with mean score }(3.79,3.71,3.57,3.60 \text { and } 3.31 \text { ) } \\
\text { agreed that rainfall, transportation, storage of watermelon, market price of watermelon and } \\
\text { Prevalence of pest and watermelon disease were the factors that affects production of } \\
\text { watermelon in the study area. The study revealed that lack of capital , poor markets, } \\
\text { perishable nature of watermelon and lack of technology for large scale production with } \\
\text { mean score } 2.38,2.19,2.17 \text { and } 2.07 \text { respectively were the serious constraints faced by } \\
\text { farmers during the cause of production. PPMC analysis ( } r=0.047,0.000,0.000 \text { and } 0.002) \\
\text { showed that there was significant and positive relationship between years of experience, } \\
\text { labour source, farm size, planting of other crops and yield of watermelon. The result of the } \\
\text { factor analysis showed that the factors affecting watermelon production were cultural } \\
\text { factor, personal/economic factor, climatic/soil factor and infrastructural factor. The } \\
\text { foregoing suggests that research institutes should make available improved seeds that are } \\
\text { not susceptible to pest and diseases to the grass-root watermelon farmers, to ensure high } \\
\text { yield and returns. } \\
\text { Copyright@2015 STAR Journal, Wollega University. All Rights Reserved. }\end{array}$ & 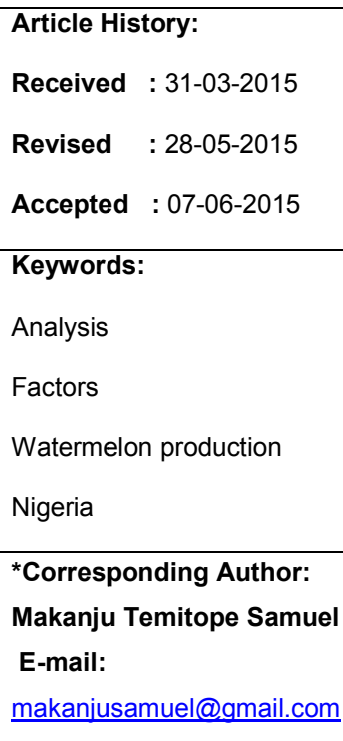 \\
\hline
\end{tabular}

\section{INTRODUCTION}

The estimated total production of watermelon in Nigeria in 2003 was 175.34 metric tons (Project Coordinating Unit and Federal Ministry of Agriculture Crop production Data, PCU/FMARD, 2004). A watermelon contains about $6 \%$ sugar and $91 \%$ water by weight. Watermelon is relished by many people across the world as a fresh fruit. This is because watermelon is known to be low in calories but highly nutritious and thirstquenching. As with many other fruits, it is a source of Vitamin C, it also contains Vitamin A in form of the disease fighting beta-carotene. Potassium is also available in it which is believed to help in the control of blood pressure and possibly prevent strokes. (Adekunle et al., 2007). Watermelon with red flesh is a significant source of lycopene. Preliminary research indicates the consumption of watermelon may have antihypertensive effects ( Figueroa et al., 2012).

Watermelon cultivation has not enjoyed a high level of technological improvements such as the use of new hybrid seeds, fertilizer and processing. Melon cultivation and processing are labor intensive. The matured and harvested fruits are collected on several spots on the farm depending on the farm size. The processing involves breaking the pod, fermentation, scooping the seeds from the pods, washing and sun-drying. Problems associated with marketing of melon include low price and unstable market prices (Yusuf et al., 2013). The problem of inaccessibility of the farmers to the modern inputs such as fertilizer, improved seeds and machineries, hence they made use of the traditional tools which limit their output and farm size (Mohammed, 2011).

Although a lot of researchers have worked on socio economic analysis of watermelon production (Mohammed, 2011), the profitability and adoption of watermelon technologies (Yusuf et al., 2013), however, very little research has been done to investigate the factors (cultural, economic, climatic, soil, etc) affecting watermelon farmers.

As a result of the importance and economic value of watermelon, it is necessary to evaluate the factors militating against the production of watermelon in Ekiti State. The study specifically describes the socio economic characteristics of the farmers, determine the factors 
Adojutelegan et al.,

affecting production and identify the constraints faced by watermelon farmers in the study area. This study will serve as a guide to prospective farmers who will like to embark on watermelon production.

\section{MATERIALS AND METHODS}

The study was carried out in Ekiti State, Southwestern Nigeria. The state is located between longitudes $4^{0} 45^{1}$ and $5^{\circ} 45^{1}$ East of the Greenwich meridian and latitudes $7^{0} 15^{1}$ and $8^{0} 15^{1}$ North of the equator. Ekiti State is in rainforest belt with a temperature range of $21^{\circ} \mathrm{C}$ to $28^{\circ} \mathrm{C}$ and high humidity. Topographically, the state is mainly an upland zone rising above 250 meters above sea level (Ekiti State Government, 2008). Ise/Orun and Emure Local Government Areas were deliberately selected for this study. The study area was selected according to research objectives and research works related to the issues. The majority of watermelon famers in Ekiti State are located in Ise and Emure. Most of the farmers are situated in Ise Ekiti (mainly Hausas). The reason behind this is as a result of the fact that Ise Ekiti is more commercialized than Emure. The hausas in ise Ekiti normally converge daily at a place called 'Sabo' after work on the farm. Watermelon harvested in the study area are sold out to various states in Nigeria like kano, (Zaria), kaduna etc. The population for the study comprised the watermelon farmers in Ise-Orun and Emure Local government, Ekiti State. Two local Government areas with highest density of watermelon farmers were selected using purposive sampling technique. With the use of snow ball technique, each farmer contacted led to other farmers and a total of 42 watermelon farmers served as the sample size. Data were collected through primary sources with the use of interview schedule to elicit information from the respondents. Data were analysed using Descriptive statistics such as frequencies count, percentages and mean score while Pearson Product Momment Correlation and factor analysis were used to test relationship between selected variables.

Correlation Analysis: Pearson's correlation coefficient when applied to a sample is commonly represented by the letter $r$ and may be referred to as the sample correlation coefficient or the sample Pearson correlation coefficient. It is used with two variables (independent and dependent) to determine a relationship/association.

Factor Analysis: Exploratory factor analysis was employed in identifying societal factors constraining watermelon production in the area. Principal component factor analysis with varimax-rotation and factor loading of 0.30 was used. Therefore, variables with factor loading of less than 0.30 and variables that loaded in more than one factors were discarded (Ashley, Amber and Anthony 2006; Madukwe, 2004).

The principal component factor analysis model is stated thus:

$\mathrm{Y} 1=\mathrm{a} 11 \mathrm{X} 1+\mathrm{a} 12 \mathrm{X} 2+* * *+\mathrm{a} 1 \mathrm{nXn}$

$Y 2=a 21 X 1+a 22 X 2+* * *+a 2 n X n$

$\mathrm{Y} 3=\mathrm{a} 31 \mathrm{X} 1+\mathrm{a} 32 \mathrm{X} 2+{ }^{* *} * \mathrm{a}+\mathrm{a} \mathrm{nXn}$

* $=$

* $=$

* $=$

$\mathrm{Yn}=\operatorname{an} 1 \mathrm{X} 1+\mathrm{an} 2 \mathrm{X} 2+{ }^{*} *+\operatorname{annXn}$

Where $\mathrm{Y} 1, \mathrm{Y} 2 \ldots \mathrm{Yn}=$ observed variables $/$ factors affecting watermelon production in the study area.
Sci. Technol. Arts Res. J., April-June 2015, 4(2): 324-329

a1 - an $=$ factor loadings or correlation coefficients.

$\mathrm{X} 1, \mathrm{X} 2, \ldots \mathrm{Xn}=$ unobserved underlying factors affecting watermelon farmers in their production

activities in the study area.

\section{RESULTS AND DISCUSSION}

\section{Socio-economic Characteristics of Respondents}

Table 1 shows the socio-economic characteristics of the respondent. Here, it could be observed that $64.3 \%$ and $35.7 \%(n=42)$ of the watermelon farmers are located in Ise and Emure Ekiti. Majority of the farmers are Hausas $(59.5 \%)$. This indicates a high level of commercial activities in Ise Ekiti. The result also shows that the majority of the respondents $(64.3 \%)$ are within the age bracket of 31-40 years which is the active and agile stage of production. Age plays significant role in farming as it determines the strength of the farmer's ability to carry out tedious and rigorous work as defined by some activities in watermelon cultivation, for example, mounting of knapsack sprayer at the back (Yusuf et.al, 2013). 76.2\% of them are married with a larger percentage $(33.3 \%$ and $26.2 \%$ ) of them with quaranic and tertiary education. This is because majority of the farmers are Hausas who migrate from the northern part of Nigeria.

Table 1: Socio-economic Characteristics of Respondents

\begin{tabular}{|c|c|c|c|}
\hline $\begin{array}{l}\text { Demographic } \\
\text { characteristics }\end{array}$ & Frequency & Percentage & $\begin{array}{l}\text { Mean } \\
\text { score }\end{array}$ \\
\hline \multicolumn{4}{|l|}{ Name of community } \\
\hline Emure Ekiti & 15 & 35.7 & \\
\hline Ise Ekiti & 27 & 64.3 & \\
\hline \multicolumn{4}{|l|}{ Ethnic group } \\
\hline Hausa & 25 & 59.5 & \\
\hline Yoruba & 17 & 40.5 & \\
\hline \multicolumn{4}{|l|}{ Age in years } \\
\hline$<30$ & 2 & 4.8 & \\
\hline $30-40$ & 27 & 64.3 & \\
\hline $41-50$ & 8 & 19.0 & 39 \\
\hline$>60$ & 5 & 11.9 & \\
\hline \multicolumn{4}{|l|}{ Marital status } \\
\hline Single & 10 & 23.8 & \\
\hline Married & 32 & 76.2 & \\
\hline \multicolumn{4}{|l|}{ Educational } \\
\hline attainment & 6 & 14.3 & \\
\hline No formal education & 14 & 33.3 & \\
\hline Quaranic & 8 & 19.0 & \\
\hline Primary & 3 & 7.1 & \\
\hline $\begin{array}{l}\text { Secondary } \\
\text { Tertiary }\end{array}$ & 11 & 26.2 & \\
\hline \multicolumn{4}{|l|}{ Primary occupation } \\
\hline Trader & 8 & 19.0 & \\
\hline Civil servant & 9 & 21.4 & \\
\hline Farmer & 25 & 59.5 & \\
\hline \multicolumn{4}{|l|}{ Family size } \\
\hline $1-5$ & 16 & 38.1 & \\
\hline $6-10$ & 8 & 19.0 & \\
\hline $11-15$ & 4 & 9.5 & 8 \\
\hline$>15$ & 14 & 33.3 & \\
\hline \multicolumn{4}{|l|}{ Farming experience } \\
\hline in years & 7 & 16.7 & \\
\hline$<5$ & 22 & 52.4 & \\
\hline $5-10$ & 12 & 28.6 & \\
\hline $11-20$ & 1 & 2.4 & 10 \\
\hline $\begin{array}{l}>20 \\
\text { Field survey (2014) }\end{array}$ & & & \\
\hline
\end{tabular}

Also, $59.5 \%$ of the respondents are really into farming activities, $21.4 \%$ are civil servants and $19.0 \%$ are traders. These assents with the study (Mohammed, 2011) that 
majority of the respondents are full time farmers. They consider that the time lag between the planting and the harvesting period can be used to run other types of business, which will serve as sources of income to sustain them during this period. The average family size among the 42 respondents was found to be 8 . This implies that the farmer will have to be responsible for a lot of things like feeding, clothing and other expenditures of the family. This will surely affect the savings of the farmer. Alternatively, this increase in family size is a determinant of the yield of watermelon. The result further shows that majority of the farmers had between 5-10 years of experience in watermelon production with an average of 10 years of experience. This result indicated that the farmers are experienced in watermelon production.

Pattern of Cropping Practices Used

Table 2 shows that Sugarbaby variety was the most popularly grown seed $(38.1 \%)$ to a crimson sweet variety
(26.2\%); kaolack (19.0\%) and Charleston gray (16.7\%). The reason for this variation in answers is as a result of differences in size, sweetness, ability to store very well and so on. Sugarbaby variety is the first variety to be introduced while the crimson sweet is a new variety in the study area. The majority of the respondents relied on both personal and hired labour for their farming operations while the rest $(35.7 \%$ and $14.3 \%)$ depend on hired only and personal labour respectively. This implies that watermelon farmers engage in some minor activities on the farm like manual weeding and hire labour for the tedious ones. A larger proportion of the farmer (40.5\%) had farm size that is greater than 3hectares. This shows that the farmers are into a large scale of production and can export their produce to other parts of the country. This results to high yield of watermelon with majority $(45.2 \%)$ of them producing more than 20tons per hectare.

Table 2: Pattern of cropping practices used

\begin{tabular}{|c|c|c|}
\hline Pattern of cropping practices used & Frequency & Percentage \\
\hline \multicolumn{3}{|l|}{ Types of watermelon seeds grown } \\
\hline Sugarbaby & 16 & 38.1 \\
\hline kaolack & 8 & 19.0 \\
\hline charleston gray & 7 & 16.7 \\
\hline crimson sweet & 11 & 26.2 \\
\hline \multicolumn{3}{|l|}{ Labour source } \\
\hline Personal & 6 & 14.3 \\
\hline Hired & 15 & 35.7 \\
\hline Both personal and hired & 21 & 50.0 \\
\hline \multicolumn{3}{|l|}{ Farm size (ha) } \\
\hline$>1$ & 4 & 9.5 \\
\hline $1-2$ & 12 & 28.6 \\
\hline $2-3$ & 9 & 21.4 \\
\hline$<3$ & 17 & 40.5 \\
\hline \multicolumn{3}{|l|}{ Yield of watermelon (tons/ha) } \\
\hline$<11$ & 6 & 14.3 \\
\hline $11-15$ & 9 & 21.4 \\
\hline $16-20$ & 8 & 19.0 \\
\hline$>20$ & 19 & 45.2 \\
\hline \multicolumn{3}{|l|}{ Types of cropping practised } \\
\hline Sole cropping & 15 & 35.7 \\
\hline Intercropping & 25 & 59.7 \\
\hline \multicolumn{3}{|l|}{ Other crops planted with watermelon } \\
\hline Cassava & 5 & 11.9 \\
\hline Maize & 6 & 14.3 \\
\hline Cuccumber & 12 & 28.6 \\
\hline Cuccumber and maize & 2 & 4.8 \\
\hline \multicolumn{3}{|l|}{ Reasons for engaging in intercropping } \\
\hline Reduced risk of plant failure & 18 & 42.9 \\
\hline Increase in income & 25 & 59.5 \\
\hline Weed control & 9 & 21.4 \\
\hline Improve soil fertility & 13 & 31.0 \\
\hline Effective land use & 17 & 40.5 \\
\hline \multicolumn{3}{|l|}{ Reasons for adopting sole-cropping } \\
\hline Good management & 14 & 33.3 \\
\hline More profit & 10 & 23.8 \\
\hline Convenient in farm management & 12 & 28.6 \\
\hline
\end{tabular}

Field survey (2014)

The $35.7 \%$ of the respondent planted watermelon as sole crop while majority $(59.7 \%, n=25)$ practiced intercropping of watermelon with cucumber $(28.6 \%$, $n=12)$, maize $(14.3, n=6)$, cassava $(11.9 \%, n=5)$, both cucumber and maize $(4.8 \%, \mathrm{n}=2)$. The respondent also gave the following reasons for engaging in intercropping: reduced risk of plant failure $(42.9 \%, n=18)$, increase in income $(59.5 \%, n=25)$, weed control $(21.4 \%, n=9)$, improve in soil fertility $(31.0 \%, n=13)$ and effective land use $(40.5 \%, n=17)$. The reasons for sole cropping include: good management $(33.3 \%, n=14)$, more profit $(23.8 \%$, $\mathrm{n}=10)$ and convenient in farm management $(28.6 \%$, $\mathrm{n}=12$ ).

\section{Factors Affecting Watermelon Production}

Table 3 reveals the various factors affecting watermelon production. Majority of the farmers with mean score $(3.79,3.71,3.57,3.60$ and 3.31$)$ agreed that 
rainfall, transportation, storage of watermelon, market price of watermelon and Prevalence of pest and watermelon disease are the factors that affects the production of watermelon in the study area. Also, some of the respondent $(54.8,38.1$ and 26.2$)$ strongly disagreed that manual weeding, land tenure and soil type affects watermelon production. In thesame vein, they disagreed $(31.0 \%$ and $26.2 \%)$ that temperature and government policies affects the production of watermelon.

Table 3: Factors affecting watermelon production

\begin{tabular}{|c|c|c|c|c|c|c|c|c|c|c|c|c|}
\hline \multirow[b]{2}{*}{ Factors } & \multicolumn{5}{|c|}{ Frequency } & \multicolumn{5}{|c|}{ Percentage } & \multirow[b]{2}{*}{ Mean } & \multirow[b]{2}{*}{ Rank } \\
\hline & SA & A & UN & D & SD & SA & A & UN & D & SD & & \\
\hline Land tenure & 9 & 8 & 4 & 5 & 16 & 21.4 & 19.0 & 9.5 & 11.9 & 38.1 & 2.74 & $8^{\text {th }}$ \\
\hline Prevalence of pest and disease & 8 & 15 & 7 & 6 & 6 & 19.0 & 35.7 & 16.7 & 14.3 & 14.3 & 3.31 & $5^{\text {th }}$ \\
\hline Government policies & 5 & 9 & 7 & 11 & 10 & 11.9 & 21.4 & 16.7 & 26.2 & 23.8 & 2.71 & $10^{\text {th }}$ \\
\hline Manual weeding & 4 & 10 & 1 & 4 & 23 & 9.5 & 23.8 & 2.4 & 9.5 & 54.8 & 2.24 & $11^{\text {th }}$ \\
\hline Rainfall & 9 & 23 & 3 & 6 & 1 & 21.4 & 54.8 & 7.1 & 14.3 & 2.4 & 3.79 & $1^{\text {st }}$ \\
\hline Temperature & 6 & 10 & 9 & 13 & 4 & 14.3 & 23.8 & 21.4 & 31.0 & 9.5 & 3.02 & $6^{\text {th }}$ \\
\hline Soil type & 5 & 9 & 9 & 8 & 11 & 11.9 & 21.4 & 21.4 & 19.0 & 26.2 & 2.74 & $8^{\text {th }}$ \\
\hline Storage of watermelon & 9 & 19 & 4 & 7 & 3 & 21.4 & 45.2 & 9.5 & 16.7 & 7.1 & 3.57 & $3^{\text {rd }}$ \\
\hline Transportation & 9 & 22 & 3 & 6 & 2 & 21.4 & 52.4 & 7.1 & 14.3 & 4.8 & 3.71 & $2^{\text {nd }}$ \\
\hline Market price of watermelon & 11 & 16 & 5 & 7 & 3 & 26.2 & 38.1 & 11.9 & 16.7 & 7.1 & 3.60 & $4^{\text {th }}$ \\
\hline Residence to farmland & 5 & 17 & 2 & 10 & 8 & 11.9 & 40.5 & 4.8 & 23.8 & 19.0 & 3.02 & $6^{\text {th }}$ \\
\hline
\end{tabular}

Note: SA-strongly agreed, A-agreed, UN-undecided, D-disagreed, SD-strongly disagreed

Field survey (2014)

Watermelon is a warm seasonal crop. Optimal crop growth if temperature is above $38^{\circ} \mathrm{C}$. Optimum temperature for germination is $28-32^{\circ} \mathrm{C}$. Watermelon not only tolerates hot weather but for best growth requires more heat than any other vegetables. It requires hot dry climate and plenty of sunshine. In rainy season it does not grow well but now a days it has been cultivated throughout the year. Continuous rainfall will reduce the sugar content in the fruit. When the temperature rises, the sugar content will also be increased (Lilly, 2013).

At temperatures below $50^{\circ} \mathrm{F}$, chilling injury can develop, causing decreased redness and juice leakage of the internal flesh, and surface pitting and Alternaria decay to the melon rind.

Melons should not be shipped in closed trucks or stored with fruits (bananas, peaches) and vegetables (tomatoes, cantaloupe) that emit ethylene. Ethylene is a colorless gas regarded as the natural aging or ripening hormone. When exposed to ethylene, watermelons breakdown internally and the flesh takes on a watersoaked appearance. This leads to flesh softening and flavor loss (Cooperative Extension Service, 2000).
Majority of the farmers carried out an average of two weeding in watermelon production. This is because watermelon suppresses weed growth after full establishment. Therefore the farmers are not faced with weeding difficulty till harvesting. Watermelon may be grown wide on variety of soils, therefore the soil type cannot affect the production. Also, there is no government policy hindering the production of watermelon in the study area and land is always allocated to any interested personalty who will like to engage in farming.

\section{Constraints Faced by Farmers During the Cause of Production}

Table 4 reveals that Lack of capital, poor markets perishable nature of watermelon and lack of technology for large scale production with mean score 2.38, 2.19, 2.17 and 2.07 respectively are the serious constraints faced by farmers during the cause of production while lack of extension services, lack of improved seeds, lack of pesticide and lack of fertilizer with mean score less than 2.00 were less serious.

Table 4: Constraints faced by farmers during the cause of production

\begin{tabular}{|c|c|c|c|c|c|c|c|}
\hline \multirow[b]{2}{*}{ Constraints } & \multicolumn{3}{|c|}{ Frequency } & \multicolumn{3}{|c|}{ Percentage } & \multirow[b]{2}{*}{ Mean } \\
\hline & V.S & SE & L.S & V.S & SE & L.S & \\
\hline Lack of fertilizer & 3 & 15 & 24 & 7.1 & 35.7 & 57.1 & 1.50 \\
\hline Lack of extension services & 8 & 23 & 11 & 19.0 & 54.8 & 26.2 & 1.93 \\
\hline Poor market & 19 & 12 & 11 & 45.2 & 28.6 & 26.2 & 2.19 \\
\hline Lack of improved seeds & 10 & 14 & 18 & 23.8 & 33.3 & 42.9 & 1.81 \\
\hline Lack of pesticide & 10 & 12 & 20 & 23.8 & 28.6 & 47.6 & 1.76 \\
\hline Lack of capital & 22 & 14 & 6 & 52.4 & 33.3 & 14.3 & 2.38 \\
\hline Lack of technology for large scale production & 13 & 19 & 10 & 31.0 & 45.2 & 23.8 & 2.07 \\
\hline Perishable nature of watermelon & 17 & 15 & 10 & 40.5 & 35.7 & 23.8 & 2.17 \\
\hline
\end{tabular}


Table 5 presents the estimates of the parameters of correlation on the factors influencing the yield of watermelon. This study revealed that there was significant and positive relationship between years of experience, labour source, farm size, planting of other crops and yield of watermelon. This indicates that an increase in all of these variables will increase the yield of watermelon. Those with large farm size and who engage themselves in planting other crops like cuccumber, maize or cassava with watermelon will experience high yield.

Table 5: correlation analysis on the relationship between socio economic variables and yield of watermelon

\begin{tabular}{lccc}
\hline $\begin{array}{c}\text { Socio-economic } \\
\text { characteristics }\end{array}$ & $\begin{array}{c}\text { Pearson } \\
\text { correlation }\end{array}$ & $\begin{array}{c}\text { Significant } \\
\text { (1-tailed) }\end{array}$ & Decision \\
\hline Age & 0.220 & 0.080 & $\mathrm{NS}$ \\
Education & -0.046 & 0.386 & $\mathrm{NS}$ \\
Family size & 0.062 & 0.347 & $\mathrm{NS}$ \\
Years of experience & $0.248^{*}$ & 0.047 & $\mathrm{~S}$ \\
Labour source & $0.558^{*}$ & 0.000 & $\mathrm{~S}$ \\
Farm size & $0.806^{*}$ & 0.000 & $\mathrm{~S}$ \\
Other crop & $0.446^{*}$ & 0.002 & $\mathrm{~S}$ \\
\hline *Significant at the 0.05 level, NS- not significant, S- Significant
\end{tabular}

The household size were not a determinant because farmers who are mainly hausas migrate to the study area without their family members thereby working on the farm themselves and most of the time hire labour to work on their farms which is significantly related to yield.

Households with increased family size exhibited significantly less loss of farm profit and yeild than farmers with less family size. An increase in farm size will increase the yield of watermelon. Likewise increase in farm size will lead to high yield. Oluyole and Sanusi (2009) had similar findings on a study carried out in Cross River State, reporting that with the desired agronomic/management practices, increased farm size will improve farm output. Farming experience was also positive and significant $(P<0.05)$. This suggests that farming experience is an important determinant of level of yeild. Farming involves a lot of risks and uncertainties; therefore to be competent enough to handle all the vagaries of agriculture, farmers must have stayed in farming business for quite some time (Ogundele and Okoruwa, 2006).

Table 6 presents the varimax-rotated factors affecting watermelon production in the area. Four (4) factors were extracted based on the response of the respondents. Only variables with factor loading of 0.30 and above at $10 \%$ overlapping variance (Ashley et al., 2006) were used in naming the factors. Variables that loaded in more than one factor as in the case of variable 3 and 4 (government policies and manual weeding) were discarded while variables that have factor loadings of less than 0.30 as in the case of variable 1 (land tenure) was not used (Enete and Amusa, 2010).

Table 6: Factor analysis of factors affecting watermelon production

\begin{tabular}{lcccc}
\hline & Cultural & $\begin{array}{c}\text { Personall } \\
\text { economic }\end{array}$ & $\begin{array}{c}\text { Climaticl } \\
\text { Soil }\end{array}$ & Infrastructural \\
\hline Land tenure & 0.275 & 0.096 & -0.047 & -0.042 \\
Prevalence of pest and watermelon disease & $\mathbf{0 . 4 4 4}$ & -0.105 & -0.058 & 0.075 \\
Government policies & 0.428 & 0.311 & 0.052 & 0.085 \\
Manual weeding & 0.635 & -0.043 & 0.595 & 0.007 \\
Rainfall & -0.008 & 0.144 & $\mathbf{0 . 4 7 5}$ & -0.078 \\
Temperature & 0.099 & 0.018 & $\mathbf{0 . 3 1 0}$ & -0.086 \\
Soil type & -0.136 & -0.151 & $\mathbf{0 . 3 2 1}$ & 0.130 \\
Storage of watermelon & 0.093 & -0.168 & 0.000 & $\mathbf{0 . 5 7 3}$ \\
Transportation & 0.044 & 0.070 & -0.077 & $\mathbf{0 . 4 7 5}$ \\
Market price of watermelon & -0.052 & $\mathbf{0 . 4 7 2}$ & 0.080 & 0.115 \\
Residence to farmland & -0.017 & $\mathbf{0 . 5 4 9}$ & -0.021 & -0.178 \\
\hline
\end{tabular}

In naming the factors, Kessler (2006) stated that each factor is giving a denomination based on the set of variables or characteristics it is composed of. This procedure was adopted in grouping the variables into four major factors as: cultural factor - factor 1, personal/ economic factor - factor 2, climatic/soil factor - factor 3 and infrastructural factor - factor 4 .

Under factor 1 (cultural factor), the specific variable affecting watermelon production in the area was: prevalence of pest and watermelon disease (0.444). Certain diseases have destroyed entire watermelon crops in some areas when weather conditions favored their development. If disease control practices are not followed, some loss can be expected every year from foliage and stem diseases (Cooperative Extension Services, 2000) .

Variables that loaded under factor 2 (personal/economic factor) include market price of watermelon (0.472) and residence to farmland (0.549). Unstable market price is a major problem facing the watermelon farmers and it affects their decision making. Most farmlands in southwestern region are far to the place of residence. Farmers always got tired after a long trek to 
their farms if they are not priviledged owning a byke or a means of transporting themselves and their produce.

Under factor 3 (climatic/soil factor) were: rainfall (0.475), temperature (0.310) and soil type (0.321). Continuous rainfall will reduce the sugar content in the fruit. Therefore watermelon needs more of temperature than rainfall. Also, watermelon can survive and grow wide on any variety of soil.

Under factor 4 (infrastructural factor) were: storage of watermelon (0.573) and transportation (0.475). The problem with Nigerian agriculture is not primarily with production but shortage of infrastructural facilities such as good road to ensure effective distribution of agriculture produce, inadequate storage and processing facilities. Ajibade (2000) confirmed that poor storage and processing facilities are some of the major problems of agriculture in Nigeria.

\section{CONCLUSIONS}

This study analysed the factors affecting watermelon farmers in ise/Orun and Emure Local Government Area, Ekiti State, Nigeria using multiple regression and factor analysis. Most of the watermelon farmers reside in Ise Ekiti and are Hausas with quranic education. The major socio-economic determinants influencing watermelon yield in the area were family size, years of experience and farm size. The identified factors affecting watermelon production include: cultural factor such as prevalence of pest and watermelon diseases, personal/economic factor such as market price of watermelon and residence to farmland, climatic/soil factor such as rainfall, temperature and soil type and lastly infrastructural factor such as storage of watermelon and transportation. The foregoing suggests that improved varieties should be developed from research institutes that will be disease and pest resistant to increase production. In addition, Government through all its agencies should make timely provision of machine, fertilizer, pesticide and other fam inputs available to farmers for hire or purchase at reduced price. Also, they should expand the provision of its social amenities such as good feeder road, trucks or trailers to hire for easy transportation of their produce.

\section{Conflict of Intereset}

Conflict of interest none declared.

\section{REFERENCES}

Adekunle, A.A., Fatunbi, A.O., Adisa, S. and Adeyemi, O.A. (2007). Growing watermelon commercially in Nigeria: An illustrated guide. USAID ICS-NIGERIA and IITA, retrieved on March, 12 2014, from http://www.fao.org/sd/erp/toolkit/ BOOKS/watermelon illust guidebook.pdf.

Ajibade, A.S. (2000). Productivity of the Nigerian Agriculture. In: Ekemode, K.O (Ed) Introduction to Agriculture for
Sustainable Development. Lagos: The Nigerian Association of Agricultural Educators (NAAGRED). Pp 2835.

Ashley, B., Amber, S.and Anthony, F. (2006). Education by Nation: Multivariate analysis. Retrieved April 22, 2008, http://www.users.muohio.edu/porterbm/Sunj/2006/start.s

Cooperative Extension Service, (2000). Commercial Watermelon Production". Cooperative Extension Service, the University of Georgia College of Agricultural and Environmental Sciences. Bulletin 996, January 2000, accessed on $12^{\text {th }}$ March , 2014.

Ekiti State Government (2008). The People of Ekiti State. Accesed on September 13, 2013 from http://www.ekitinigeria.net/

Enete, A.A. and Amusa, T.A. (2010). Determinants of Women's Contributions to Farming Decisions among Cocoa-based Agroforestry Households in Ekiti State, Nigeria. FACTS Reports 4(1).

Figueroa, A., Sanchez-Gonzalez, M.A., Wong, A., Arjmandi, B.H. (2012). Watermelon extract supplementation reduces ankle blood pressure and carotid augmentation index in obese adults with prehypertension or hypertension. American journal of hypertension 25 (6): 640-3.

Kessler, C.A. (2006). Divisive Key-Factors Influencing Farm Households Soil and Water Conservation Investment. Journal of Applied Geography 26: 40-60.

Lilly, V. (2013). Watermelon Production in Tamilnadu-At a Glance. Cultivation patterns, health benefits, watermelon: Indian Journal of Applied Research 3(6).

Madukwe, M.C. (2004). Multivariate Analysis for Agricultural Extension Research. In Terry. A. O.(Ed) Research Methods in Agricultural Extension. Pp 206-236.

Mohammed, B.T. (2011). Socio-economic analysis of melon production in Ifelodun Local Government Area, Kwara State, Nigeria. Journal of Development and Agricultural Economics 3(8): 362-367.

Ogundele, O. O. and V. O. Okoruwa. (2006). Technical Efficiency Differentials in Rice Production Technologies in Nigeria. AERC Research Paper 154, Nairobi, Kenya. Retrieved March 10, 2014 from http://www.aecrafrica.org/ documents/rp 154.pdf

Oluyole, K.A. and Sanusi, R.A. (2009). Socio- Economic Variables and Cocoa Production in Cross River State, Nigeria. Journal of Human Ecology 25(1):5-8.

PCU/FMARD (2004): Project Coordinating Unit and Federal Ministry of Agriculture Crop production Data in Nigeria.

Yusuf, S.F.G, Lategan, F.S. and Ayinde, I.A., (2013). Profitability and Adoption of Watermelon Technologies by Farmers in Moro Local Government of Kwara State, Nigeria. Journal of Agricultural Science 5(5). 